\title{
Go to Darwin and Starve, Ya Bastard: Theorizing the Decline of Third Tier Cities
}

\author{
Tara Brabazon
}

Family stories weave in and out of sanitised, reified national histories. Colonized nations such as Australia, the United States, Canada and Aotearoa / New Zealand are built on a pioneering myth of white 'settlers' and 'explorers' moving through a landscape and 'discovering' mountains and rivers. The 'other side of the frontier' [1] - of genocide, sickness and institutional racism against indigenous peoples who were not granted the right of citizenship - sits uncomfortably within the propulsive narrative of progress and economic development. These stories summon unexpected, interwoven histories of progress and development, injustice and discrimination. My parents - both in their eighties - maintain distinctive stories that cut through the clouded narratives of colonialism. Kevin and Doris Brabazon married in Broome in 1950. Broome is a coastal town in the north-west corner of Western Australia. After his Perth-based apprenticeship, Kevin started work as a carpenter at the Broome meat works. Doris worked in Streeter and Male, the general store of the town.[2] Doris had just turned 20. Kevin was 23. Broome was a tough, but intriguing place. My mother describes it as a town of music, money, fun and laughter. White men and women lived in the town, but were not dominant. Yawuru men and women were the majority,[3] even though they did not have the rights of citizenship or the freedom of movement below the Tropic of Capricorn.[4] Strong minority communities were also present from Japan, many having faced internment during the war, [5] China, Indonesia and the Philippines. [6]

One man living in Broome at this time was Con Gill.[7] A Jamaican who was mentioned in Ion Idriess' Forty Fathoms Deep,[8] Gill was a pearl diver at the height of the industry. By the time Doris and Kevin arrived in Broome, Con was an ageing man near the end of his life, as was the pearl shell industry itself.[9] Yet Con is not the star of his own life story. Instead, attention is placed on an unnamed white cockatoo.[10]

Con lived in or near - or spent much of his time in or near - the Continental Hotel.[11] Unmarried, his companion was a cockatoo with a rather large vocabulary, much of it gleaned from drinkers at the Continental. His most memorable phrase, pronounced to anyone who would listen, was "Go to Darwin and starve, ya bastard." Significantly, if a cockatoo had learnt this phrase, it must have been uttered frequently and consistently. Cockatoos are like an analogue tape recorder, but with feathers.

What makes the phrase both evocative and worthy of discussion is that it emerged from Broome. This town is 2,200 kilometres (1,400 miles) from Perth. The capital city of Perth is known as the most isolated in the world. [12] Yet Broome revealed another layer or level of isolation. Residents managed tropical heat, huge tides, irregular transportation, uneven and scarce food supplies, and seasonal tourism and tourists. Currently, the population of Broome is growing, recorded at 12,000 at the last census, but expanding to 45,000 during the tourist season, including the Shinju Matsuri Festival.[13] It is a small, arid and isolated place, with patches of beauty and a diversity in population beyond the scale of many cities. Yet the cockatoo carried a different story: a love of Brome and a deep derision for - and competitiveness with - another small and isolated town: Darwin.

Darwin at the time of the cockatoo's derision was damaged, still recovering from Japanese bombing during the Second World War. It was a place of even fewer women than Broome and suffered from - or ecstatically enjoyed - 
an even wilder reputation. From the isolation of Broome, the pejorative labelling of Darwin had bite and must have been common enough for a cockatoo to learn and use.[14]

This article for Fast Capitalism uses this phase to understand third tier cities and the relationship between them. These small urban environments do not have the profile of global cities like New York, London, Tokyo or Cairo, or second-tier cities, like San Francisco, Manchester, Osaka or Alexandria. There is a wide gap in the city imaging literature when attempting to grasp the challenges of these small places. This article explores these cities and towns that are not well known or internationally branded, but are facing structural economic issues worsened after the Global Financial Crisis, and therefore needing to invent new reasons for their existence.

To commence such a study requires a clear presentation of how cities are defined, constituted, develop, decline and build relationships with other urban environments. To clarify and enable this research requires an early discussion of the types, modes and tiers of cities.

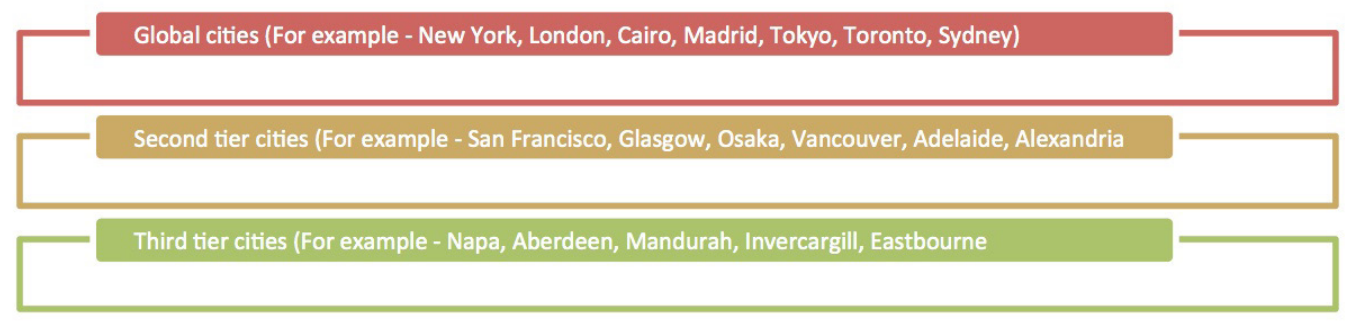

Figure 1: Global, second tier and third tier cities

Cities are defined relationally. So are the relationships between cities and towns. Definitions are dynamic and relational. A city is larger than a town. A town is larger than a village. But the population size, rights and responsibilities that constitute these distinctive markers of urbanity are not transferable between nation states. Number of residents is not a reliable indicator. In Australia, the determination of a 'city' is statistically constituted, being given to a place with a minimum of 10,000-30,000 people. This wide variance in population is necessary as there is a difference between states, with Tasmania at the lower end, and Western Australia at the top of the scale. Reviewing the complexity of systems - for transportation and sanitation for example - is often a better indicator. Some of the historic cities in the United Kingdom are small in terms of population, with towns attracting much larger numbers. In the United States, a 'city' has delegated powers from a state and county, but the population size required to be granted this authority is distinctive to each State. In the New England states - Massachusetts, Maine, New Hampshire, Vermont, Rhode Island and Connecticut - it is determined by mode of government, rather than population. A town is unincorporated and holds no governmental powers to deliver services. New Zealand maintains distinct and particular characteristics to define and determine a city. It must, "have a minimum population of 50,000, be predominantly urban in character, be a distinct entity and a major centre of activity within the region." [15] Therefore, while a precise and trans-national definition of cities and towns would be advantageous, there are internal distinctions between states and provinces within a nation, and wide variations between nations. There are historical legacies, fortuitous discoveries and random events that have shaped the fortunes of cities and towns. Yet the key strategy of the last decade to manage this diversity is a policy, strategy and portfolio held within the phrase 'creative industries.'

\section{Creative Industries after the Global Financial Crisis}

Cities have signified excitement, movement, chaos, political intrigue and opportunity since - at least - the industrial revolution. Karl Marx and Friedrich Engels developed the theories for political change while watching the twisting Manchester landscape, bending and buckling under the speed of economic and social change caused by the textile industry. In the century that followed, urbanity was marketed, gentrified and celebrated, displacing the industrial tailings and poor health of the workforce. Since the first set of creative industries policies were instigated by the 
Tony Blair government in 1997, economic development and city development have been tethered. Researchers such as Richard Florida,[16] Charles Landry[17] and Charles Leadbeater[18] have aligned progress with urbanity. There is a positive correlation between urbanization and per capital income.[19] Efficiencies in agriculture allow a population to move into cities. [20] Through the history of the creative industries, the challenges and specificities of small, thirdtier cities have been under-discussed. Indeed, a series of proxies - such as the presence of a gay community[21] or 'bohemians'[22] - have been the building blocks of a creative city. This has meant that assumptions have dominated the creative industries literature. The most damaging and seductive is the theory of cultural modelling. Researchers suggest that the practices that operate well in San Francisco in the United States or Manchester in England will have a relevance and resonance in Wagga Wagga or Invercargill. Indeed, even the relevance of Manchester's regeneration to Bolton, Blackburn or Morecambe is questionable.

Such assumptions create sloppy thinking. Regeneration has become a bland word or one that defaults to an automatic positive connotation. The examples from the United Kingdom in the late 1990s and 2000s showed that urban regeneration emerged in the context of neoliberalism, when public services and funding were reduced.[23] Regeneration meant - simply - a boost in building construction. Yet the personal and public resolve and planning required to regenerate the lives of residents - through thinking about work, leisure, education and family life - were not conducted. Phil Jones and James Evans presented this process ruthlessly - but with productive bite.

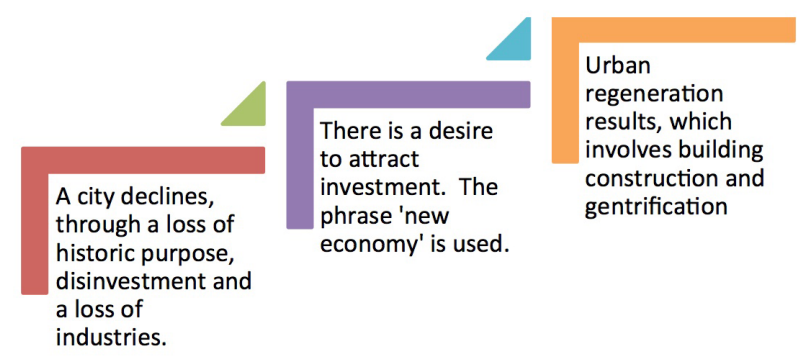

Figure 2. Diagram constructed by Tara Brabazon, based on Phil Jones and James Evans, Urban Regeneration in the UK, (Los Angeles: SAGE, 2008)

After 'urban regeneration,' how is development sustained, particularly if this 'development' only 'improved' the central business district? Buildings and the 'investments' that follow are a mask for deindustrialization, depopulation, environmental damage and decrepit infrastructure.[24]

Perhaps the most important emerging concepts in understanding urbanity are sustainability and resilience.[25] Global cities continue to do well, attracting the money, businesses and well educated population. But this creates deep inequalities and imbalances of wealth.[26] Third tier cities are left with the poor, the less educated, the less mobile and the less skilled.[27] They are places of residuals, waste and deficits. Therefore, the assumption that a neoliberal model of urban regeneration (constructing buildings) is generalizable to struggling small cities is flawed at best and delusional at worst. This is not only a mode of metrocentricity, it is also global-metrocentricity. As Howell realized, "large populations bring their own amenities and agglomeration effects ... making consolidated cities more attractive."[28] While strategies like creative industries are valuable, the generalizability of these strategies should now be deeply questioned, particularly considering the imbalance of research away from third tier cities. Some of this research involves an engagement with troubled and decaying local governments.

The maturity of a council can be ascertained through how they structure the relationship between economic development and culture, creativity, the arts and media. An example of a flawed and dated structure that did not recognize the changing relationship between producers and consumers is Bathurst Regional Council, a small city in inland Australia. Even in the 2010s, they have four departments that structure their activities.

- $\quad$ Corporate Services \& Finance

- $\quad$ Engineering Services

- Environmental, Planning \& Building Services

- Cultural \& Community Services.[29]

Culture and community arts are described as a 'service.' City planning and 'building' is structurally separated 
from culture. Conservative and elitist conceptualizations of 'culture' permeate these structures. This council remains locked in older models of economics and culture, derived from the creative arts and cultural policy. The economic potential of popular music, design and sport is unmentioned and unrepresented. On the website, the council does not offer entrepreneurial initiatives or opportunities, using popular culture, to create economic development. The minimal innovative cultural development in Bathurst is a testament to the structural separation of art and commerce.

An alternative way of conducting council business is revealed in Bathurst's near neighbour. Dubbo City Council has configured itself as a growing city with a large catchment area of influence.[30] 'Recreation and culture' is a focus, rather than 'the arts.' Because of this changing nomenclature, they were able to attract a national live event: JJJ's One Night Stand. Held in April 2013, the Council not only welcomed this opportunity and windfall, but also created value-added potential for local businesses. [31] Popular music developed tourism and shopping. Dubbo offers a solid model for creative industries and city imaging. Cultural policy is always economic policy. The changes in economics - globalization, digitization, hyper consumption and increasing interests in intellectual property rights and copyright - are radical reconfigurations in cultural life.[32] While Dubbo has been able to capture events, there are some structural limitations such as a slowness to build creative institutions like theatres. There are limitations in selling a city to and for families. A greater diversity of interest and motivation is required to both sustain and grow a small city. Families are diverse. They transform, and parents will leave if there are not opportunities for social and cultural growth. Alternative modes of social organization include single and divorced men and women, gay partnerships, and trans-generational family units of ageing parents and adult children. The focus on a particular model of 'families' where two parents raise children is not generalizable. It is promotable. It is simple, clean and crisp branding, requiring little innovation or imagination. A recent study - reported widely in the Australian press - listed the most 'family friendly' cities. Perhaps not surprisingly, third tier cities were over-represented in this list.[33] In conservative times, it is easy to perpetuate the narrative of small cities as insular (inward), safe (dull) and dependable (lacking imagination and dynamism). These are "place based social norms" [34] that can have a debilitating effect on the men and women that do not fit within the narrow definitions of love, sex, intimacy and families. These everyday geographies do matter. Innovative councils must welcome a complex palette of interpersonal relationships, rather than build administrative barriers that block the formulation of linkages and alignments that dynamically transform through the life cycle.

Mapping small cities for Fast Capitalism, urban development can also be categorized as fast, slow and still.[35]
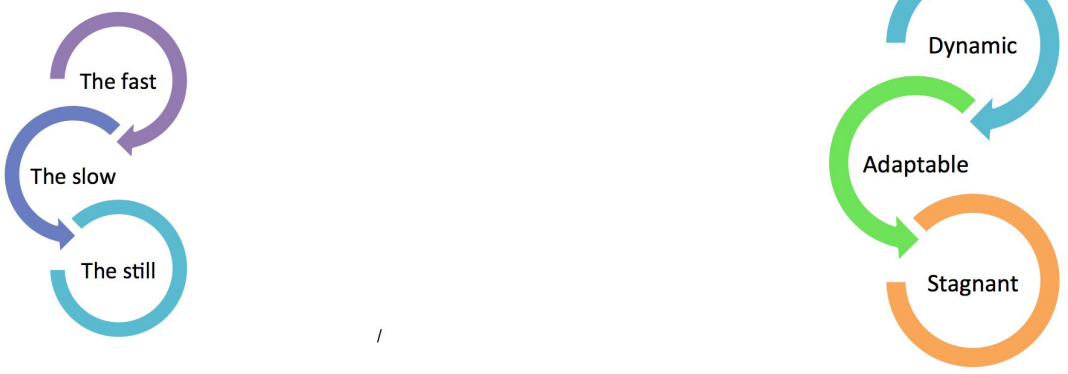

Figure 3. A model of city time, derived from a phrase by G. Duranton, "Urban evolutions: the fast, the slow, and the still,"

Figure 4. How cities and their citizens manage change American Economic Review, Vol. 97, No. 1, 2007, pp. 197-221

Global cities are associated with speed, movement and change. There is dynamism in managing a changeable context. Second tier cities are more embedded in their histories but can mobilize opportunities if and when they are presented. The Beatles emerged from Liverpool. Beatles tourism grew from the 1980s. The Lord of the Rings film series was managed from Miramar near Wellington in New Zealand. The slower, third tier cities often rely on agricultural rather than industrial time - using seasons - rather than the vagaries of a stock market opening and closing.

Therefore, spaces and times, geographies and histories, the land and the clock, create a momentum for change, 
or a blockage to innovation.

Education is important, particularly in these neglected areas and regions. There is a provocative maxim to consider: the smaller the city, the more important the university. While second tier cities have multiple institutions and global cities feature a matrix of further and higher education options, the small cities often feature only one university, or the outlier campus of a larger university. For example Murdoch University in Western Australia has its central campus in the suburb of Murdoch in Perth, but two smaller campuses in Rockingham and Mandurah in the now booming southern corridor of the state. This Peel campus in Mandurah is very small[36] and - most importantly - offers highly restricted courses.[37] Even with these restrictions and limitations, this is still a valuable contribution to a region. John Hogan, the registrar at Newcastle University in the United Kingdom, verified the accuracy of this assumption about universities and small cities.

Imperial [College London] is a fantastic institution, but if it closed, would London notice? Probably not. But if Newcastle closed, or Northumbria, Durham, Teesside or Sunderland [universities] closed, it would be a catastrophe for the local and the bigger region, because there's not a lot else going on in the North East ... The relative importance of these universities is so much more important than some of the outstanding institutions you might find in London.[38]

This role is increasingly crucial because - as Richard Muir from the Institute for Public Policy Research revealed - regional inequality increases when public spending declines. He suggests that, in the UK context, “ $£ 1$ million output by a university generated a further $f^{1.38}$ million for the wider economy.”[39] Therefore, in a declining economy, regional injustices heighten, and at such a time, the economic role and significance of a university is amplified.

The dearth of education in many post-industrial cities helps explain why these places have had such trouble reinventing themselves. They've also suffered because their model of having vast firms in a single industry stunts entrepreneurship and innovation.[40]

This is the double bind. A single industry employed a city's workers, but there were few opportunities to retrain, because of the lack of educational opportunities. That is why universities matter so much, particularly when situated in third tier cities.

What happens to the people who are not 'smart' and 'collaborative,' or flexible in a neoliberal economy? Guy Standing has argued that a new class - the precariat - is being formed.[41] It is an evocative word, capturing a movement from stability and certainty with work and home. It is a life of fracture, fissures and dense instability. This is the group of casualized workers that personally assumed the risk of capitalism. If the business was losing money, then casual staff could be sacked and rehired if required. This is a transfer of risk from employer to employee. The outcome is "temporary career-less workers." [42] Because third tier cities have less complex economic options for alternative employment, the problems of the precariat are particularly severe. Workers - historically - have possessed the 'double freedom' to sell their labour but be 'free' from the means of production.[43] Yet in times of labour surplus, this last freedom dissipates.

After the Global Financial Crisis and rise of the precariat, the assumptions, theories and models of branding and urban regeneration not only appear brittle but corrosive. As Joel Kotkin has argued,

\begin{abstract}
Among the most pervasive, and arguably pernicious, notions of the past decade has been that the "creative class" of the skilled, educated and hip would remake and revive American cities. The idea, packaged and peddled by consultant Richard Florida, had been that unlike spending public money to court Wall Street fat cats, corporate executives or other traditional elites, paying to appeal to the creative would truly trickle down, generating a widespread urban revival ... Indeed in many ways the Floridian focus on industries like entertainment, software, and social media creates a distorted set of economic priorities. The creatives, after all, generally don't work in factories or warehouses. So why assist these industries? Instead the trend is to declare good-paying blue collar professions a product of the past. [44]
\end{abstract}

'Cool cities,' such as San Francisco, do not provide methods, strategies, trajectories or scenarios for assisting deindustrialized cities, particularly with an un(der)employed working class. The sleight of hand was that the underemployed, post-skilled working classes in Detroit, Stoke or Newcastle (in Australia) would move from their assembly lines and work in service industries, making coffee, preparing food or selling clothes or mobile phones. This shift did not eventuate.

The Global Financial Crisis was the honest - indeed brutal - mirror that made the followers of Richard Florida - capitalism's Dorian Gray - recognize the flaws in their theories and research. By January 2013, Richard Florida admitted this reality in public.[45] He noted that, "the past couple of decades have seen America sort itself into 
two distinct nations, as the more highly skilled and affluent have migrated to a relatively small number of cities and metro areas." [46] He did not hear the Benjamin Disraeli echo in his words, [47] or assess the impact of this 'sorting' on reinforcing inequality.[48] Cities with skilled workers increased their skill. The others suffer and decline as the educated, the skilled, the young and the tax payers leave one location and move to another.

On close inspection, talent clustering provides little in the way of trickle-down benefits. Its benefits flow disproportionately to more highly-skilled knowledge, professional and creative workers whose higher wages and salaries are more than sufficient to cover more expensive housing in these locations. While less-skilled service and blue-collar workers also earn more money in knowledge-based metros, those gains disappear once their higher housing costs are taken into account.[49]

This reality was masked before the Global Financial Crisis. The surplus capital from finance and real estate could be used for branding, promotion and advertising of other - particularly media - industries. Manufacturing and agricultural industries were neglected, with the focus on universities and the service sector. After the GFC, an array of workers required jobs, stability, security and reliable funding for housing and health. Instead, the precariat emerged.

Like much of the creative industries ideologies, the urban planners and local governments were sold smoke, mirrors and a band aid, all of which proved weak and irrelevant when buffeted by the whiplash of finance capital. Macgillis's critique was not only seething, but personal.

In April 2006, the Richard Florida show arrived in the Southern Tier of Upstate New York. It was only one of the scores of appearances this decade by the economic-development guru, whose speaking fee soared to \$35,000 not long after his 2002 book The Rise of the Creative Class made him a star on the lecture circuit. Cleveland, Toledo, Baltimore, Greensboro, Green Bay, Des Moines, Hartford, Roanoke, and Rochester were among the many cities that had already shelled out to hear from the good-looking urban-studies professor about how to get young professionals to move in ... Of course, none of these burgs has yet completed the transformation from post-manufacturing ugly duckling to gay-friendly, hipster swan. But middling results elsewhere did not keep people in the greater Elmira area from getting excited about Florida's visit. They listened as, in his stylish suit and designer glasses, he related his blue-collar upbringing outside Newark before segueing into his secrets of urban success in the 21 st century: the "three T's" of technology, talent, and tolerance. If cities could make themselves appealing to the Web designers, architects, biomedical researchers, and other innovators who are now the drivers of economic growth, then they would also attract the businesses that want these footloose pioneers to work for them.[50]

These 'post-manufacturing' burgs were also small third tier cities. Their manufacturing past was the reason for their foundation, infrastructure and population. But production and consumption remained in industrial models. Regeneration failed. The 'creative class' did not arrive. Neither did tourists. Third tier cities were the canary in the mine. They function at the mono-industrial edge of capitalism, showing the cost of simple solutions - of marketing and branding - to dense, complex and structural economic and social weaknesses.

Because so much of the creative industries neglected manufacturing and agriculture, focusing instead on the service sector, media industries and tourism, it did not take root in small cities. The best use of creative industries involves the deployment of design and skill development to 'value-add' to agricultural products and manufactured goods. A wine industry uses branding and design strategies to provide information about the region in which the grapes are grown.[51] Tourism is enabled and other produce in the area is promoted and supported. There are still large groups of workers around the world who live in and on manufacturing, mining, construction and agriculture. The problem is that Charles Leadbeater's title - Living on thin air[52] - was taken literally. But copyright and intellectual property rights are the start of economic development and a new income stream. They are not the entirety of the economy.

If Florida and the first wave of creative industries researchers were wrong - which they were - then what can be gleaned from the creative industries and city imaging theories after the GFC? There remains real people with real families, housing (particularly mortgage) crises, health crises and transportation crises in third tier cities. They were living in Daniel Bell's post-industrial society.[53] This is not only a question of earning a predictable and stable salary. There is a provocative link between health, wealth and inequality.[54] A 'good life' is difficult to create or measure and requires attention to health and a secure, reliable income.[55] It is imperative that there are educational opportunities to retrain for new opportunities in employment, and participation in community life. How are these to be managed? To answer this question, my next section focuses on the specificities of third tier cities.

\section{Entering the Third Tier: A Tour through Decay and Disadvantage}

Third tier cities are not only neglected in the research literature, but lack infrastructural and policy support.[56] 
It is difficult for these areas to gain an identity and image. These cities are incredibly diverse in shape, population size and economic 'development.' Erickcek and McKinney located and categorized eight types of small cities:

1. Dominated by an older industry in decline.

2. Private-sector dependent, with little public sector employment

3. Dispersed geography and function

4. Company towns attempting to survive when a company leaves

5. University and college cities where graduates leave after graduation

6. Company towns surviving after the company leaves, but with a remaining social purpose

7. Cities growing through the engine of the new economy and creative industries

8. Cities growing through university/government/business clusters. [57]

This is a strong rubric to map and categorize third tier cities. A key book in this under-researched field that captures this diversity is the edited collection from David Bell and Mark Jayne: Small cities: urban experience beyond the metropolis.[58] The contributors investigate the consequences of inter-city competitiveness. The overarching argument from the researchers is that the strategies that have worked in San Francisco and Manchester are not (necessarily) applicable to Bathurst, Mandurah, Invercargill, Bolton or Oshawa.

Unable to replicate the strategies of second-tier cities like Manchester, Osaka or Seattle and without an intervention from public or private investment or higher education institutions, third-tier cities stagnate or decompose. The question, raised by Beth Siegel and Andy Waxman, is whether this decline is unstoppable.

Unfortunately for these cities, many of the sources of strength that they drew upon in their heyday are now disadvantages in the New Economy. For example, their rich industrial heritage was the result of large, densely built factories that were constructed to take advantage of the transportation modes of the day - waterways and railroads. In the New Economy, employers prefer an entirely different sort of location - sprawling one-story buildings near highways and advanced telecommunications lines, or in larger, more vibrant cities ... As jobs moved out of these small cities, a host of other problems followed: declining population, loss of the middle class, abandoned mill buildings with environmental legacies, struggling downtowns, a shrinking tax base, and fewer employment opportunities.[59]

Jobs vacate these small cities, along with population. Downtowns struggle. The tax base reduces. The difficulty in retaining young people and attracting new residents is profound. These third tier cities exist throughout the world and the strategies to enable their recovery are diverse. Superficial attention to branding and city imaging are not sufficient. Siegel and Waxman realized that, "while the data demonstrate that third-tier cities are having difficulty transitioning to the New Economy, a more thorough understanding of these cities is needed, an understanding that goes well beyond statistics." [60]

To address Siegal and Waxman's realization, I propose a four-layered strategy for this understanding of small urban environments. Firstly, it is important to grasp the specificity of the city's history, noting the period of its greatest economic and social success, along with its causes, consequences and legacy. A second stage is to recognize the present environment and reality of living in this city, including the social and institutional gaps and challenges. Thirdly, it is beneficial to explore the similarities and differences with other third tier cities around the world, noting effective and inefficient strategies for change. Finally, a city modelling imperative, where applicable strategies in one city are then attempted in another, may provide either a longer-term pathway to growth or a temporary tactic to sustain a current situation while other policies are discovered and researched. Cities are not a "growth machine."[61]

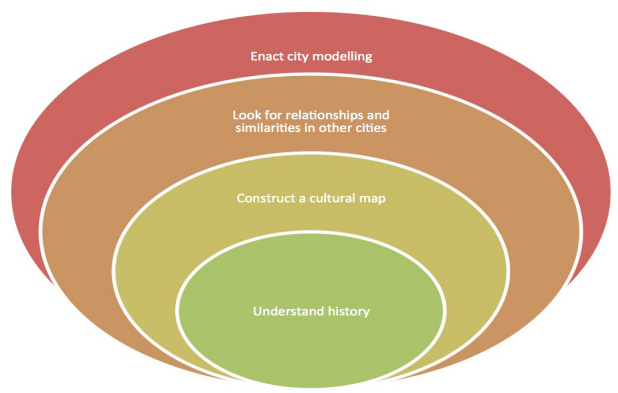

Figure 5. Stages to intervene in third tier city development (Outward development) 
Many third tier cities gained a successful single industry in the manufacturing and industrial age. Flint in Michigan and Oshawa in Canada manufactured motor vehicles.[62] Napa (still) makes wine and has flourishing wine-tourism enterprises. Blackpool was a destination for working class tourism. Rockhampton in Australia was a service hub for the cattle industry with a huge meat works.

These cities are rarely known beyond their nation. They are not marketed or branded. So third tier cities were successful in the manufacturing/industrial age, but have failed in the new knowledge economy. The housing and transportation in the third tier is inadequate.[63] The infrastructure was based on factories and the construction of small homes for the workers to service the industry. The telecommunication systems and mobile networks are inadequate. Therefore, the jobs reduce and employment in 'the new economy' - particularly in the service sector, creative industries and education - move to global and second tier cities. [64] Because of the lack of employment, the population is declining, the middle class are leaving, and health and educational facilities are reducing. Abandoned and derelict buildings proliferate. Environmental problems, hazards and pollution result from the after effects of deindustrialization. Downtowns are deserted. Shops close because of the lack of population. Young people leave for global cities where work and leisure opportunities are a draw card. What remains are commuter cities that are often desolate, decomposing and decaying.

The third tier city - although under-researched - offers much to scholars particularly with regard to local culture, theories of economic and social decline and rejuvenation. Unable to replicate the strategies of Melbourne, Vancouver or Manchester, without infrastructural investment, they may stagnant and decompose without careful, incisive and specific policy development. Most gained a purpose and focus through the industrial revolution and Fordism.[65] After post-industrialization, attraction and retention of migrants becomes a concern. [66] But in an environment of creative industries, knowledge economy and Leadbeater's Living on Thin Air,[67] these third tier cities began to lose their purpose.

There are opportunities for these small cities to recover and bloom. Some cities adjust to change. Others do not. Landry presented some reasons for this pattern of success, failure and transformation.

Successful cities seemed to have some things in common - visionary individuals, creative organizations and a political culture sharing clarity of purpose.[68]

Third tier cities lack these attributes. They lack the policy structures to build relationships between sectors. Art is separated from economics. Certainly, there is no checklist for recovery. There is little evidence that confirms the transferability of strategies between struggling cities.[69] What may work in Dubbo will not function in Hastings. What operates in Margate may not succeed in Invercargill. However outlining these strategies, policies and plans that have worked in a third tier city does offer opportunities and strategies that are rarely available because a lack of research. As David Bell and Mark Jayne realized,

Small cities have been ignored by urban theorists who, in seeking to conceptualize broad urban agendas and depict generalizable models (for example relating to epochal urbanism, the structure and nature of the urban hierarchy, global cities and global city-regions), have tended to obscure as much as they illuminate. Given that study of 'the city' has been vital to broader advances in the social sciences, this neglect of smaller urban centres has profound consequences for urban studies.[70]

This 'neglect' also has consequences for economic development, managing social inequalities and enabling access to not only the infrastructure but the opportunity to participate in sport and leisure, and to develop healthy individuals and communities. Long commutes sap both life and time. Importantly, many workers live in third tier cities and work in global cities. For example, Eastbourne is an affluent - if uneven - town in the extreme south east of England. It is a 90 minute train trip to London Victoria, with the first train leaving the station at 5:08am. [71] This train is filled with men working in London, alongside a few holidaymakers catching an early flight and disembarking at London Gatwick station. But the impact of three hours of commuting time each day must be recognized in all areas of a person's life. Relationships suffer.[72] Health declines.[73] Political engagement reduces.[74] One key solution to these nagging and corrosive social problems is that third tier cities be economically more robust and resilient, so that individuals, couples and families can live in these small cities and towns, but also work within them. By alleviating the commute, an array of new social and economic relationships can be formed. The key is to create jobs in these places. 


\section{| When a Place Finds a Purpose}

What do a car race, apple blossom festival and an Elvis weekend have in common? The answer is that each of these events creates tourism, profile and economic development in third tier cities in the Central West of New South Wales in Australia. Such strategies combine entrepreneurialism, natural advantages in the landscape and luck. Urban environments, at their best, create a matrix of landscape, economic development and social behaviour. This allows organic and productive relationships to emerge between these variables, creating imaginative, dynamic and innovative patterns in daily life.[75]

The generic policies for the creative industries and city imaging provide the basic framework to consider the changing nature of urbanity. The problem is how to decode, translate and filter these agendas for very distinctive environments and outcomes. I understand these challenges, having worked in small cities in Canada, England and Australia. Currently, I am resident in Bathurst, one of a series of inland cities in New South Wales that arc out from Sydney. This chain of inland cities is unusual, particularly considering that $80 \%$ of the Australian population hug the coast. Bathurst is an important site of study for this article. Known for 'the great race'- the Bathurst 1000[76] - it offers both international branding and an economic spike for the city each year. Yet there remains ambivalence from the residents. This event is separate and distinct from the lived experience of this small city.

Bathurst fits the profile of third tier cities and yet maintains an aspiration and trajectory for change. This city was - and is - best known as the home of a day-long motor race. It is an educational hub that houses Charles Sturt University. It (almost) manages the pull towards Sydney,[77] but suffers from a poor transportation infrastructure, particularly with regard to cheap and publically-available facilities. A similar example is Luton in the United Kingdom, which also houses a university (Bedfordshire), but is too close to London to resist its pull, and lacks the specificity of event management. Oshawa in Canada now has a university - the University of Ontario Institute of Technology - but is tethered to the global centre of Toronto. Bolton in the north of England also maintains a university, but it is part of the Lancashire towns that are collapsing into Greater Manchester. Bathurst is internationally unusual because it features one major, internationally-known sporting event.

Universities matter to this analysis, but cannot be a solitary singular engine for development. Often forgotten are the diversity of employment opportunities in a university, and its tethered service industries. While academics are the most visible, a large suite of administrators - from finance to human resources to legal and governance to information technology - are required. Cleaning and hospitality staff are needed, alongside an array of shops and services to keep this large organization in food, clothing and an array of services such as banking, stationery, security, software, hardware and books. Universities - in and of themselves - are complex organizations. That is why they matter in third tier cities, which were often mono-industrial in their formation. Rendering such spaces, economies and populations complex is a challenge. But universities are a strong first step in enabling this diversity.

Nicos Komninos developed the phrase "intelligent cities." [78] This concept builds on the configurations of learning regions and organizational learning to develop “regional systems of innovation.”[79] Attendant to such systems is an understanding of the actors in this system, how they interact, and the technology available to create competitive strengths over other regions. When extended, an "intelligent city" emerges, integrating individual, collective and artificial intelligence in a specific setting. [80] The goal is to create innovation through social cooperation. [81] While Komninos does not mention the role of schools and universities in such a scheme, online learning offers an extraordinary opportunity to collaborate, innovate and disseminate, serving to brand and market the university in the process.

For third tier cities, event management is the key. They cannot dominate space, but they can dominate a (short) period of time in their region, and perhaps nation. The key challenge is to mobilize event management to improve the life of residents in the city. Greg Richards and Robert Palmer confirmed that events can "help 'make' places.' [82] They show how events can render cities more liveable and how they can be the carrier for wider social, economic and cultural objectives.[83] Their key examples are from the European Capital of Culture (ECOC) programme that has been held since 1985. Their research - published after the Global Financial Crisis - captured the stark nature of choices available for cities.

Cities of today face two choices. Either they develop to meet the challenges created by the pace of global change, or they resist the impulse for transformation and stagnate. At a time when economic systems are no longer predictable, in order to remain competitive, cities are turning to strategies that focus on their own innate resources their histories, spaces, creative energy and talents. [84] 
This is particularly poignant considering the infrastructural neglect of most third tier cities. The small city is confronting challenges, but the marketing (or at least the definition) of 'creative energy' is necessary. While the meaning of such a phase is ambiguous, it is obvious that for certain regions, they need (desperately) Richard Florida and the creative industries / city imaging discourse to hold at least some truth: "The new centrality of culture in urban policy was linked to a series of externalities, such as the need to stimulate economic growth, the need to bolster social inclusion and the changing urban landscape." [85] Within such a statement, the marketing of culture becomes the economic strategy of last resort. When the city becomes a stage, infrastructure becomes a prop.

Events such as festivals are crucial to third tier cities. Their success is reliant on transforming a concept, historical accident or imaginative idea into a practical application and outcome. It is a movement from ideas into experiences. Put another way, this is the movement from city marketing to city branding. [86] Global and second tier cities dominate film festivals (Toronto, Cannes, Venice and Berlin). But food offers enormous potential for third tier cities - particularly when they are the gateway or hub for agricultural regions. A fine example from Halifax is 'Catch,' the Nova Scotia Seafood Festival.[87]

Creative industries and city imaging policies, strategies and agendas will look different in these places. But they will claim a moment in time, rather than a generic branding or marketing strategy. Budgets will be small. Goals which may become key performance indicators - will be conservative, long-term and difficult to measure. Part of the challenge to address is neglect. The dominance of finance capitalism in global cities - alongside the boom in 'lifestyle' capitalism in second tier cities - means that third tier cities and towns are decentred, marginalized, denied and forgotten. Therefore the 'brand' of these cities has never been addressed directly. It is difficult to start this process now because of the hyper-availability of information via the read-write web that discredits and undermines the life of those living in these places.

There are ten questions that may assist policy makers, small and medium sized businesses and public sector enterprises when considering how to develop, enhance, sustain and grow third tier cities.

1. Is the city or town invisible beyond hyper-local affiliations? Consider strategies for event management to build national and international profile.

2. Is primary production, mobile goods or digitally-delivered materials key areas of economic development? Consider the development of an integrated, place-specific, social media campaign. Geosocial networking may also be an option.

3. What are the costs and benefits of marketing the city or town as 'family friendly'? Are there facilities and opportunities to experience a good life for single people, couples and multiple ages?

4. Does the city have a university resident within it? Is this institution being used effectively? Are academics deployed by councils and community organizations for their expertise? Are the possibilities for life-long learning promoted for the residents?

5. Are health and fitness facilities available for residents of multiple ages and abilities? If weather is not temperate, are indoor facilities available?

6. Is plentiful, fresh and high quality food available to residents? Are there a diversity of supermarkets and primary producers to provide alternatives to fast food outlets?

7. Is the city walkable? What strategies - such as geosocial networking - can be deployed to increase the interest in moving through the city?

8. Are both high and popular culture supported in the city? Can bands be formed and play and DJs perform at local events, as much as ensembles and orchestras?

9. Evaluate the local government departments and structures. Are entrepreneurial opportunities enabled, or is there a structural separation of economic and cultural development?

10. How effective is the transportation network? If there is an airport, how regular and reliable are the flights moving to global and second tier cities? How regular are trains that not only connect to global cities, but link small cities and towns?

This article has probed, framed and explored how smaller cities are managed, transformed or left to decline. In reality, cities matter because the lives, hopes, aspirations and goals of so many people are reliant on the availability of work, safe and clean food, enjoyable leisure and exercise, transportation and the capacity to build a network of friends, acquaintances and relationships. The goal is to create - as Mitchell, Frank, Harris, Dodds and Danforth have described - "the geography of happiness."[88] Half the world's population live in urbanity. In reality, we must discuss urbanities. Creative cities - of coffee shops, tasteful electronic music and polo shirts - are not the archetype that Richard Florida proposed. Education cities, which may be smaller and less dynamic but earnestly committed to teaching, learning, reading and thinking, may also be valued. Many of these cities are small and stable but with a rhythm punctuated by reading and thinking, rather than talking and espresso. Others may value high quality food, sport and walkability. They create great pride, because they offer a deep belonging. This pride can result in the story 
that started this article, about a white cockatoo that had been taught by Broome residents who loved their location so much, that all other competing places were only worthy of humour and ridicule. There is an edgy joy in Con's cockatoo reminding listeners - if they dislike Broome - to "go to Darwin and starve, ya bastard."

Walter Benjamin described Paris as the "capital of the 19th century." [89] This phrase is evocative, because he demonstrates how global cities not only occupy space, but time. Similarly - and following on from Benjamin - New York was the capital of the 20th century. That is why the destruction of the World Trade Centre's Twin Towers on September 11, 2001 was so provocative, shocking, startling but disturbingly symbolic. The New York century was over. The capital of the 21st century is yet to emerge. Beijing or Mumbai are both contenders. Third tier cities will never dominate their space or time. But the residents within them can live local lives of resilience, sustainability, accountability, responsiveness and responsibility. These cities and towns can dominate a few seconds on the national and - perhaps - international clock through a sporting event, a quirky festival or a tragic event. Bathurst, Glastonbury and Lockerbie remain provocative examples of these three categories. They are thrust into the light through sport, music or calamity. Yet for the men, women and children who live a life 'hiding in the light,' [90] there is an opportunity to summon a new way of living, learning, earning and thinking.

\section{Endnotes}

1. Henry Reynolds explores these alternative, often genocidal histories in An indelible stain?, (Ringwood: Viking, 2001)

2. Although recorded later, the $A B C$ current affairs programme 4 Corners went to Broome at the moment it was transitioning from its primary industry: sourcing mother of pearl before the arrival of plastics, which destroyed the market. Please refer to "4Corners in Broome 1962," ABC, http://www.abc.net.au/local/ videos/2010/12/02/3083134.htm

3. Two language groups lived in the Broome region: the Yawuru and Jungun. By 2006, the Yawuru gained Native Title for the area around Broome. This region was approximately $5000 \mathrm{sq} \mathrm{km}$.

4. This dedication and commitment to the land remains. Please refer to "Bardi Jawi," Department of the Environment, Government of Australia, http:// www.environment.gov.au/indigenous/ipa/declared/ bardijawi.html

5. D. McNamara and J. Coughlan, "Recent trends in Japanese migration to Australia and the characteristics of recent Japanese immigrants settling in Australia," Japanese Studies, Vol. 12, No. 1, 1992, pp. 50-73

6. A fascinating recent article captured the intimate nature of some of these relationships. Please refer to R. Balint, "Aboriginal Women and Asian Men: A Maritime History of Color in White Australia," Signs, Vol. 37, No. 3, Spring 2012, pp. 544-554

7. Con Gill - along with his 'parrot' - is mentioned as a 'colourful personality' in a family history "Adams and Associated Families in Australia 1830-2013," http:// members.iinet.net.au/ nbradley/Adams-o/p14.htm
8. I. Idriess, Forty Fathoms Deep: pearl divers and sea rovers in Australian waters, (Sydney: Angus and Robertson, 1937). This is a rare, out of print book with few records online. However there is a reference in the online review website GoodReads. Please refer to "Forty Fathoms Deep," GoodReads, https://www. goodreads.com/book/show/4096689-forty-fathomsdeep

9. It was to be replaced with a still-thriving cultured pearl industry that is very successful because of Broome's king tides. Please refer to "Australia's Pearling Industry," Australia.gov.au, http://australia.gov.au/ about-australia/australian-story/australias-pearlingindustry

10. As cockatoos (often called umbrella cockatoos) can live over fifty years, Con and his cocky may indeed have spent much of their adult lives together. It is believed Con Gill died in 1955.

11. "The old Continental Hotel," NLA, http://nla.gov. au/nla.pic-vn 4361595

12. The corrective is often that Perth is the most isolated continental capital city in the world. Honolulu is actually more isolated from neighbouring cities. Please refer to Life on Perth, http://www.lifeonperth. com/facts.htm

13. Shinju Matsuri Festival, http://www.shinjumatsuri. com.au/

14. Fascinatingly, the film Australia was based in and around Darwin for much of the story. However the shooting of pre and post-bombing Darwin was conducted in four states and territories: Queensland, Western Australia, New South Wales and the Northern Territory. Because of the scale of transformations 
to Darwin, it was necessary to discover and deploy locations that still sustained some historical features. For a discussion of the film Australia, please refer to Fiona Lake, http://www.fionalake.com.au/other-info/otherreferences/music-films-books/australia-film-story\#set

15. "City," New Zealand Government, 2006, http:// www.stats.govt.nz/Census/about-2006-census/2006census-definitions-questionnaires/definitions/c.aspx

16. R. Florida, The Great Reset: how new ways of living and working drive post-crash prosperity, (New York: HarperCollins, 2010)

17. C. Landry and F. Bianchini, The Creative City, (London: Demos, 1995)

18. C. Leadbeater, Living on thin air: the new economy, (London: Penguin, 2000)

19. J. V. Henderson, "Cities and development," Journal of Regional Science, Vol. 50, No. 1, 2010, pp. 515-540

20. G. Michaels, F. Rauch and S. Redding," Urbanization and structural transformation," Quarterly Journal of Economics, Vol. 127, No. 2, 2012, pp. 535-586

21. The relationship configured between the presence of gay men and women and the development of creative industries is one of the oddest proxies configured by Florida and his colleagues. In many ways, it is inverted, backwardly mapped research. San Francisco is 'gay friendly' and the place of small and creative startups. There is not necessarily - or indeed actually - any relationship between these variables. However there is research that probes the lives of lesbian, gay, bisexual and queer citizens in small cities. A fascinating study that probes the metrocentric nature of gay narratives is Tiffany Muller Myrdahl, "Ordinary (small) cities and LGBQ lives," ACME, Vol. 12, No. 2, 279-304

22. R. Florida, "Bohemia and economic geography," Journal of Economic Geography, Vol. 2, No. 1, 2002, pp. 255-271.

23. P. Jones and J. Evans, Urban Regeneration in the UK, (Los Angeles: SAGE, 2008), p. 9

24. An outstanding article that investigates the relationship between climate change, environmental damage and aging infrastructure is David Satterthwaite's “The political underpinnings of cities' actuated resilience to climate change," Environment and Urbanization, Vol. 25, 2013, pp. 381-391

25. Satterthwaite particularly probes the concept of resilience and the capacity to manage the shocks of climate change, ibid., p. 381. A powerful book using the concept has also emerged. Please refer to P. Newman, T. Beatley and $\mathrm{H}$ Boyer, Resilient cities: responding to peak oil and climate change, (Washington: Island Press, 2009)
26. Jones and Evans, op. cit., p. 54

27. ibid., p. 53

28. M. Howell, "The logic of urban fragmentation: organizational ecology and the proliferation of American Cities," Urban Studies, July 11, 2013, p. 2

29. Bathurst Regional Council, Council Departments, http://www.bathurst.nsw.gov.au/council/ departments

30. Dubbo City Council, http://www.dubbo.nsw.gov. au

31. Special Opportunities for Dubbo businesses, March 27, 2013, Dubbo City Council, http://www.dubbo.nsw. gov.au/BlogRetrieve.aspx?PostID=315452\&A=Search Result $\&$ SearchID $=5898359 \&$ ObjectID $=315452$ $\&$ ObjectType $=55$

32. S. Tepper, "Creative assets and the changing economy," The Journal of Arts Management, Law and Society, Vol. 32, No. 2, Summer 2002, 159-168

33. S. Elsworth, "Where are our family friendly cities," Daily Telegraph, January 13, 2014 http:// www.dailytelegraph.com.au/news/national/ where-are-our-familyfriendly-cities/story-fni0xqrc1226813308737 ? sv $=66 \mathrm{e} 30 \mathrm{dd} 34 \mathrm{~b} 5421 \mathrm{~b} 9 \mathrm{~d} 8 \mathrm{f} 9 \mathrm{a} 3 \mathrm{~b} 5 \mathrm{c} 815$ fb0b\#.UunABcc27VA.facebook

34. T. Muller Myrdahl, "Ordinary (small) cities and LGBQ lives,” ACME, Vol. 12, No. 2, 2013, pp. 279-304

35. G. Duranton, "Urban evolutions: the fast, the slow, and the still," American Economic Review, Vol. 97, No. 1, 2007, pp. 197-221

36. "Peel Campus," Murdoch University, http://www. murdoch.edu.au/About-us/Our-profile/Campuses/ Peel-campus/

37. A bridging course, nursing and counselling courses, and masters and doctoral supervision are available, Peel Courses, Murdoch University, http://handbook. murdoch.edu.au/courses/?\&loc=Peel

38. J. Hogan in S. Cunnane, "'Univer-cities' told to learn some home truths," Times Higher Education, May 3, 2012, p. 8

39. R. Muir, ibid.

40. ibid., p. 255

41. G. Standing, The precariat: the new dangerous class, (London: Bloomsbury, 2013)

42. ibid., p. 14

43. K. Marx, Capital, Vol. 1, (London: Penguin Classics, 1990), 874-875 
44. J. Kotkin, "Richard Florida concedes the limits of the creative class," joelkotkin.com, March 20, 2013, http:// www.joelkotkin.com/content/00717-richard-floridaconcedes-limits-creative-class

45. R. Florida, "More losers than winners in America's new economic geography, The Atlantic, January 2013, http://www.theatlanticcities.com/jobs-andeconomy/2013/01/more-losers-winners-americas-neweconomic-geography/4465/

46. Ibid.

47. B. Disraeli, Sybil, or the two nations, Project Gutenberg, http://www.gutenberg.org/ files/3760/3760-h/3760-h.htm

48. A potent discussion of the 'austerity' ideology that followed the credit crunch is Mark Blyth's Austerity: the history of a dangerous idea, (Oxford: Oxford University Press, 2013). He stated that, "when those at the bottom are expected to pay disproportionately for a problem created by those at the top, and when those at the top actively eschew any responsibility for that problem by blaming the state for their mistakes, not only will squeezing the bottom not produce enough revenue to fix things, it will produce an even more polarized and politicized society in which the conditions for a sustainability politics of dealing with more debt and less growth than undermined," p. 15

49. Florida, "More losers than winners in America's new economic geography," op. cit.

50. ibid.

51. For example, please refer to T. Brabazon, M. Winter, B. Gandy, Digital Wine, (Berlin: Springer, 2014)

52. C. Leadbeater, Living on thin air: the new economy, (London: Penguin, 2000)

53. D. Bell, The coming of post-industrial society: a venture in social forecasting, (New York: Basic Books, 1976)

54. A. Deaton, The great escape, health, wealth and the origins of inequality, (Princeton: Princeton University Press, 2013)

55. To provide one example of these problematic wages in small cities, a recent study confirmed that one third of Hull's residents are earning below a living wage. Please refer to "Third of Hull workers earn less than a living wage," Hull Daily Mail, January 17, 2014, http://www. hulldailymail.co.uk/Hull-workers-earn-living-wagefigures/story-20450208-detail/story.html

56. D. Bell and M. Jayne, in "Conceptualizing small cities," stated that "the woeful neglect of the small city in the literature on urban studies means that we don't yet have to hand wholly appropriate ways to understand what small cities are, what smallness and bigness mean, how small cities fit or don't' fit into the 'new urban order,' or what their fortunes and fates might be," from D. Bell and M. Jayne (eds.), Small cities: urban experience beyond the metropolis, (Abingdon: Routledge, 2006), p. 2

57. G. Erickcek and H. McKinney, Small Cities Blues: Looking for Growth Factors in Small and Medium-Sized Cities, Upjohn Institute for Employment Research, Working Paper 04-100,2004, http://research.upjohn. org $/ \mathrm{cgi} /$ viewcontent.cgi article $=1117 \&$ context $=u_{-}$ workingpapers, pp. 16-22

58. D. Bell and M. Jayne, Small cities: urban experience beyond the metropolis, (Abingdon: Routledge, 2006)

59. Beth Siegel and Andy Waxman, "Third-tier cities: adjusting to the new economy," Reviews of Economic Development Literature and Practice, No. 6, 2001, http://www.eda.gov/ImageCache/EDAPublic/ documents/pdfdocs/1g3lr_5f8_5fsiegel_2epdf/ v1/1g3lr_5f8_5fsiegel.pdf

60. ibid.

61. H. Molotch, "The city as a growth machine: toward a political economy of place," The American Journal of Sociology, Vol. 82, 1976, pp. 309-332

62. G. Macaluso, "Oshawa automotive capital of Canada," Windsor Star online, February 7, 2012, http://blogs.windsorstar.com/2012/02/07/oshawaautomotive-capital-of-canada/

63. M. Grieco and F. Raje, "Stranded mobility and the marginalization of low income communities," paper for the Urban Vulnerability and Network Failure, SURF, Manchester, April 29-30, 2004

64. T. Barnes and T. Hutton, "Situating the new economy: contingencies of regeneration and dislocation in Vancouver's inner city," Urban Studies, Vol. 46, No. 5 and 6, May 2009, http://www.geog.ubc. $\mathrm{ca} /$ tbarnes/pdf/PAPER_Situating_Vancouver's_ new_economy.pdf

65. L. Brown, L. Lobao, A. Verheyen, "Continuity and change in an old industrial region," Growth and Change, Vol. 27, Spring 1996, pp. 175-205; B. Castro, "Manufacturing jobs, local ownership, and the social health of cities: a research note," The Responsive Community, Winter 1997/98, pp. 63-66; K. Dudley, The End of the Line: lost jobs, new lives in postindustrial America, (Chicago: University of Chicago Press, 1994); B. Harrison, "Industrial districts: old wine in new bottles?" Research in Urban Economics, Vol. 9, 1993, pp. 3-26

66. H. Krahn, T. Derwing and B. Abu-Laban, "The retention of newcomers in second- and third tier cities in Canada," Prairie Centre of Excellence, Working Paper Series, WP01-03, May 2004 
67. C. Leadbeater, Living on Thin Air, (London: Penguin, 1999)

68. C. Landry, The Creative City, (London: Comedia, 2004), p. 3

69. Bill Baker realized that, "recommending the destination marketing practices of Las Vegas, New York City, and San Francisco to small cities is hardly appropriate. We have specifically designed this book for those ambitious communities that recognize that they must adopt the principles of a branded approach, despite having a modest budget," Destination Branding for Small Cities, (Portland: Creative Leap Books, 2007), p. 11

70. D. Bell and M. Jayne, "Small cities? Towards a research agenda," International Journal of Urban and Regional Research, Vol. 33, No. 3, September 2009, pp. 683-99

71. Eastbourne to London Victoria, National Rail timetable, http://ojp.nationalrail.co.uk/service/ timesandfares/EBN/VIC/tomorrow/0445/dep

72. M. Pamer, "Long Commutes take toll on marriages," August 14, 2013, NBC Los Angeles, http://www. nbclosangeles.com/news/local/Long-Commutes-TakeToll-Marriage-Relationships-Study-219612751.html

73. B. Everett, "Community: what a long trip to work is doing to your health," Women's Agenda, August 14, 2013, http://www.womensagenda.com.au/guilt-freezone/health/commuting-what-a-long-trip-to-work-isdoing-to-your-health/201308132703

74. S. Inskeep and S. Vedantam, "Study: Commuting adversely affects political engagement," NPR, November 19, 2013, http://www.npr.org/2013/11/19/246085202/ study-commuting-adversely-affects-politicalengagement

75. M. Middleton, "Cities: resident readers and others," from I. Parker (ed.), Critical Textwork, (Buckingham: OUP, 1999), pp. 117-118

76. Bathurst 1000, http://www.bathurst1000.com.au/
77. It is rare for workers to live in Sydney and commute to Bathurst. The distance is too great, the trains too slow and the flights too unreliable. Some academics at Charles Sturt University do manage this arrangement through working at home for some part of each week. But enacting a commute as exists between Luton and London or Eastbourne and London would not be possible.

78. N. Komninos, Intelligent Cities: Building 3rd Generation systems of innovation, http://uwforum. org/upload/board/intel-cities-overview-citycollege-2008.pdf

79. ibid., p. 17

80. ibid., p. 23

81. ibid., p. 26

82. G. Richards and R. Palmer, Eventful Cities: cultural management and urban revitalization, (Amsterdam: Elsevier, 2010), p. vii

83. ibid.

84. ibid., p. 2

85. ibid., p. 10

86. ibid., p. 270

87. Catch, http://www.thecoast.ca/halifax/catch-thenova-scotia-seafood-festival/Event?oid=1697601

88. L. Mitchell, M. Frank, K. Harris, P. Dodds and C. Danforth, "The geography of happiness: connecting Twitter sentiment and expression, demographics, and objective characteristics of place," PLoS ONE, Vol. 8, No. 5, 2013.

89. W. Benjamin, "Paris - Capital of the 19th Century," http://nowherelab.dreamhosters.com/paris $\% 20$ capital.pdf

90. D. Hebdige, Hiding in the Light, (London: Routledge, 1988) 